In summary, this book can be recommended to neurologists and neurosurgeons, and trainees in those disciplines, as a short, succinct, and reasonably complete introduction to the anatomy and physiology of the CSF, and to the clinically relevant forms of brain edema and rationale for management. Readers seeking a more comprehensive review of the subjects, particularly the CSF, will need to consult other works.

James W. Schmidley, $M D$

Pediatric Neurology for the House Officer (3rd Ed.) by H.L. WEINER, D.K. URION, and L.P. LEVITT, 228 pp., ill., Baltimore, Williams \& Wilkins, 1988. $\$ 15.95$

This book of 228 pages, designed "to outline succinctly important clinical information about common pediatric neurological problems," fits in a pocket. Sections are arranged by topic, including guidelines to what information should be elicited, differential diagnosis, treatment, and prognosis, with suggested readings. Very brief reviews of neuroanatomy and development end the text.

The text appears free of significant errors. Some information was of course omitted; $\mathrm{eg}$, the fact that Depakote capsules are available in more than 1 dosage. Pathophysiology receives bare treatment. The reproduction of the Denver Developmental Screening Test is difficult to read. There is no coherent summary of the neurologic examination, although there are 8 pages devoted to foreword, preface, and acknowledgments.

This book is the best pocket manual in its field. It provides a great deal of basic, practical, accurate information in an accessible format. In addition to being a portable companion, the text offers a concise review, and it costs less than $\$ 20$.

Ronald Sims, $M D$

\section{Fetal Neurology (The International Review of Child Neurology)}

edited by ALAN HILL and JOSEPH J. VOLPE, 317 pp., ill., New

York, Raven Press, 1989. $\$ 69.00$

Child neurologists who see newborns in intensive care units have come to rely on the work of Drs. Hill, Volpe, and a few others for guidance. The environment is busy, the patients are difficult to evaluate, and their problems are frustrating. There is little for us to offer the infants after brain injury has occurred. Our efforts must protect the brain before birth; we need to understand fetal neurology.

Monitoring fetal well-being has been the task of obstetricians and perinatologists. Most of the book's 18 contributors work in those specialties, and the book is primarily aimed at neurologists and neurosurgeons. The first 2 sections review antepartum and intrapartum assessment; the last section is devoted to a few specific fetal conditions. Most chapters are followed by a commentary by Drs. Hill and Volpe, which provide the unifying, neurologic perspective.

Antepartum evaluation of the fetus consists mainly of the contraction stress test and the nonstress test. They are established methods but do not predict cerebral injury. Drs. Prechtl and Rayburn describe continuous, ultrasound monitoring of fetal movements. This new research allows intrauterine neurologic examination; one may even stimulate the fetus with sounds which elicit startles and blinks. The data collected thus far show that movements follow predictable patterns in a normal fetus. The hope is that a biophysical score can be compiled which would reflect fetal well-being. Fetal movements, breathing, heart rate, and amniotic fluid volume would contribute to the score, which is discussed in a chapter of its own.

The research of Dr. Jason Birnholz shows remarkable ultrasound images of fetal faces and eye movements. The morphology of the eye and the development of eye movements may be useful clues to brain development and function.
Intrapartum problems may result in brain injury, although what proportion of lasting injuries happen during labor and birth is not known. As neurologists are the ones who most often diagnose brain injury in early life, we need to understand clearly the value and limitations of intrapartum monitoring of the placenta, fetal blood, and heart rate.

The last section provides the somewhat contrasting views of Drs. Manwaring and Chervenak on fetal hydrocephalus. Dr. Manwaring is a neurosurgeon. Dr. Chervenak is a perinatologist; he also contributed a chapter on fetal spina bifida. The last chapter by Drs. Jacob and Sarnat reviews brain effects on muscle development.

Fetal Neurology will mainly interest neurologists who care for newborns. For neonatal neurologists, much of this book will be either completely new or will provide reviews of established monitoring methods. Perinatologists and neurosurgeons will also find a few chapters of the book useful. Doctors and parents of sick newborns owe Drs. Hill and Volpe thanks again for compiling knowledge about the immature brain and for stimulating research on ways to evaluate and protect it from lasting harm.

Gerald F. Tremblay, $M D$

Etiology of Dementia of Alzheimer's Type (Report of
the Dahlem Workshop on Etiology of Dementia of Alzheimer's Type, Berlin 1987, December 6-11) edited by A.S. HENDERSON and J.H. HENDERSON, 250 pp., ill., Chichester, UK, John Wiley \& Sons, 1988. \$72.95

This report summarizes the presentations and discussions of a multidisciplinary group of investigators at the Dahlem Workshop held in Berlin in 1987. The organizers hoped that this interaction would provide new insights and suggest new areas for investigation.

The book includes 13 background papers and 4 group reports. The background papers are grouped roughly into 4 categories corresponding to the group reports: risk factors, expression and symptomatology, cell injury: molecular biology and genetic basis, and relationship of normal aging and dementing diseases in later life. Some of the papers (such as J. Mortimer's "Do psychosocial risk factors contribute to Alzheimer's disease?") are particularly clear expositions that stimulate consideration of neglected areas of Alzheimer's disease research. Several of the papers, however, are simply summaries of reviews that have been previously published elsewhere. The 4 group reports are useful summaries of the discussions, conclusions, and areas of further research as determined by the participants in each of the 4 areas. Throughout the text, terms and abbreviations are used inconsistently, and there are an annoying number of typographical and grammatical errors. In addition, the price is rather high.

Even with the above limitations, the book will be of interest to many Alzheimer's disease researchers and would be a valuable addition to larger medical libraries.

Douglas J. Lanska, $M D$

\section{Movement Disorders: A Comprehensive Survey}

by WILLIAM J. WEINER arid ANTHONY E. LANG, 735 pp., ill., Mount Kisco, NY, Futura Publishing Company, 1989. $\$ 125.00$

The authors of this book have succeeded in providing a review of the current understanding and treatment of movement disorders. The organization of the volume is well thought out and syndromeoriented. Each clinical entity is discussed along with a review of relevant anatomy, biochemistry, physiology, and pathology. Diagnosis and treatment are also covered; Parkinson's disease (including the MPTP story), Wilson's disease, and Huntington's disease receive separate chapters. A disadvantage of the syndromic organization is that some chapters encompass a variety of pathophysiologic processes. The chapter on akinetic-rigid syndromes, for instance, in- 


\title{
Neurology
}

\author{
Fetal Neurology (The International Review of Child Neurology) \\ Gerald F. Tremblay \\ Neurology 1989;39;1275-1275-a \\ DOI 10.1212/WNL.39.9.1275-a
}

This information is current as of September 1,1989

\section{Updated Information \& \\ Services}

Permissions \& Licensing

Reprints including high resolution figures, can be found at:

http://n.neurology.org/content/39/9/1275.2.citation.full

Information about reproducing this article in parts (figures,tables) or in its entirety can be found online at:

http://www.neurology.org/about/about_the_journal\#permissions

Information about ordering reprints can be found online:

http://n.neurology.org/subscribers/advertise

Neurology ${ }^{\circledR}$ is the official journal of the American Academy of Neurology. Published continuously since 1951, it is now a weekly with 48 issues per year. Copyright (C) 1989 by AAN Enterprises, Inc.. All rights reserved. Print ISSN: 0028-3878. Online ISSN: 1526-632X.

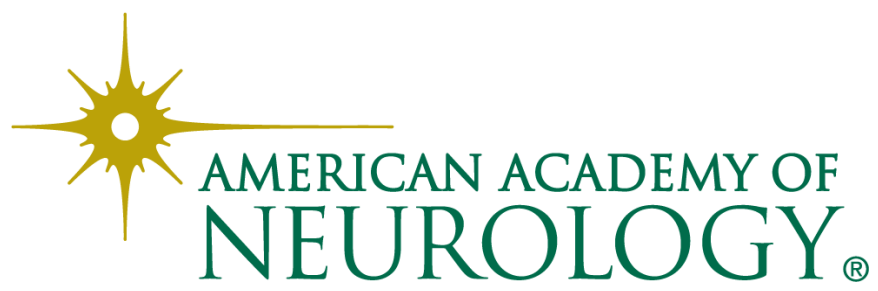

